\title{
Fruit production and quality of guava as a function of biofertilizer and nitrogen fertigation in Brazilian semiarid
}

\author{
E. A. Santana1, Í. H. L. Cavalcante ${ }^{1,2 *}$, D. de S. Brito ${ }^{1}$, R. N. do Carmo ${ }^{1}$, K. dos S. M. de Sousa ${ }^{1}$ \\ ${ }^{1}$ Federal University of São Francisco Valley, Agronomy Engineering, Petrolina (PE), Brazil, ${ }^{2}$ Researcher fellow of the National Council for \\ Scientific and Technological Development (CNPq), Brazil
}

\section{A B S T R A C T}

\begin{abstract}
Adequate agronomic management is crucial to reach high guava yields that demand a well-defined fertilizer management, including organic fertilizer such as biofertilizers, which have emerged as an important component of the integrated nutrient supply system aiming environmentally better nutrient supply using fertigation systems in Brazil. This way, an experiment was carried out to evaluate the fruit production and quality of guava as a function of biofertilizers and $\mathrm{N}$ fertilizing in brazilian semiarid. The experimental design was in randomized blocks with treatments distributed in a factorial arrangement $(5 \times 2)$ referring to biofertilizer concentrations [0, 2.5, 5.0, 7.5 and $10 \%$ ] and mineral fertilizing with $\mathrm{N}$ (fertilization with $50 \%$ and $100 \%$ of recommended $\mathrm{N}$ ), with four replications of five plants each. Fruit quality and production of guava depend on bovine biofertilizer and $\mathrm{N}$ fertigation. Biofertilizer promotes significant enhancements on fruit firmness, vitamin $\mathrm{C}$ and $\mathrm{pH}$, beyond titratable acidity reduction of guava. It is possible to recommend fertigation with biofertilizer at $5.66 \%$, independently of $\mathrm{N}$ fertilizing with $50 \%$ or $100 \%$ of recommended $\mathrm{N}$. Bovine biofertilizer is an important key to the production of guava under semiarid climate.
\end{abstract}

Keywords: Alternative fertilizer; Post-harvest; Psidium guajava

\section{INTRODUCTION}

São Francisco Valley is the main Brazilian region of growing irrigated fruits, especially mango, grape, guava, coconut and acerola (IBGE, 2016). Among the fruit crops grown in São Francisco Valley, guava detaches with production of nearly $106.3056 \mathrm{t}$, corresponding to $32 \%$ of all guava produced in Brazil (IBGE, 2016).

Fertigation is a commonly used for growing guavas in São Francisco Valley, due to it's a proven tool efficiency for uniform and balanced nutrient distribution since it provides water and nutrient availability in the higher root activity area of plant canopy, especially if a localized irrigation is used (Chavez and Torres, 2012).

One of the nutrients applied through fertigation is nitrogen $(\mathrm{N})$ which is the second nutrient more required by guava tree and it is essential for plant growth and development, as an essential constituent of amino acids, enzymes, nucleic acids, and chlorophyll (Marschner, 2012). A negative feature of $\mathrm{N}$ fertigation is possible groundwater contamination and $\mathrm{N}$ loss to the atmosphere, since plants are not able to absorb all $\mathrm{N}$ of the fertilizer.

One possibility to mitigate $\mathrm{N}$ fertilizer excess is partial or total replacement by organic fertilizers such as bovine biofertilizer, which is an organic matter source able (or not) to supply $\mathrm{N}$ plant demand, it can also be supplied through fertigation, it is decomposed faster than solid fertilizers, has low-cost distribution and fast organic matter decomposition (Gross et al., 2008).

Biofertilizer has positive effect soil physical and chemical characteristics (Pires et al., 2008) and consequently on plant growth and development, and, fruit production and quality (Gross et al., 2008). Especially for fruit quality it is registered in the scientific literature the biofertilizer effect on improving or maintaining fruit quality of yellow passion fruit (Dias et al., 2011; Cavalcante et al., 2012), papaya

\footnotetext{
*Corresponding author:

I. H. L. Cavalcante, Researcher fellow of the National Council for Scientific and Technological Development (CNPq), Brazil.

E- mail: italo.cavalcante@univasf.edu.br
}

Received: 22 September 2016; Revised: 08 February 2017; Accepted: 14 February 2017; Published Online: 24 February 2017 
(Mesquita et al., 2007), custard apple (Leonel et al., 2015) and banana (Santos et al., 2014; Senthilkumar et al., 2014). For guava Chavez and Torres (2012) compared organic and conventional production systems partially replaced by biofertilizer applied through fertigation and reported that biofertilizer was better than other treatments. Additionally, Batista et al. (2015) concluded that organic inputs use for growing guavas beyond synthetic inputs provides high fruit yield and fruit quality compatible to market demands for soluble solids, $\mathrm{pH}$, titratable acidity, pulp firmness and soluble solids/titratable acidity ratio.

Hence, the present study aimed to evaluate the fruit production and quality of guava as a function of biofertilizers and $\mathrm{N}$ fertilizing in Brazilian semiarid.

\section{MATERIAL AND METHODS}

\section{Plant materials and growth conditions}

Guava (Psidium guajava) plants cv. Paluma propagated by cuttings were used in this study.

The study was carried out from July 2014 to August 2015 (two consecutive trials) on the experimental farm of Federal University of São Francisco Valley, Petrolina County, Brazil. The climate of this region is classified as Bswh (Köeppen), which corresponds to a semiarid region.

During the execution of the experiment, the climatic data were collected by a meteorological station installed inside the experimental site (Fig. 1), while physical and chemical characteristics of the soil before the experiment are in Table 1. The soil is a Yellow Argisol (Ultisol - American classification Soil Taxonomy).

One year old guava plants, spaced $4 \mathrm{~m}$ between rows and $4 \mathrm{~m}$ between plants, were daily micro-sprinkle irrigated with

\begin{tabular}{|c|c|c|}
\hline \multirow[t]{2}{*}{ Soil characteristic } & \multicolumn{2}{|c|}{ Value } \\
\hline & $0-20 \mathrm{~cm}$ & $20-40 \mathrm{~cm}$ \\
\hline Organic matter (\%) & 0.56 & 0.53 \\
\hline $\mathrm{pH}$ (in water) & 6.2 & 5.4 \\
\hline $\mathrm{Ca}^{2+}\left(\mathrm{cmol}_{\mathrm{c}} / \mathrm{dm}^{3}\right)^{\mathrm{b}}$ & 2.1 & 2.0 \\
\hline $\mathrm{Mg}^{2+}\left(\mathrm{cmol}_{\mathrm{c}} / \mathrm{dm}^{3}\right)^{\mathrm{b}}$ & 1.4 & 1.2 \\
\hline $\mathrm{Al}^{3+}\left(\mathrm{cmol}_{\mathrm{c}} / \mathrm{dm}^{3}\right)^{\mathrm{b}}$ & 0.0 & 0.0 \\
\hline $\mathrm{K}^{+}\left(\mathrm{cmol}_{\mathrm{c}} / \mathrm{dm}^{3}\right)$ & 0.74 & 0.63 \\
\hline $\mathrm{Na}^{+}\left(\mathrm{cmol}_{\mathrm{c}} / \mathrm{dm}^{3}\right)$ & 0.11 & 0.19 \\
\hline$P(\mathrm{mg} / \mathrm{dm} 3)^{\mathrm{a}}$ & 207.0 & 58.0 \\
\hline Clay (g/kg) & 95 & 11 \\
\hline Silt (g/kg) & 32 & 60 \\
\hline Sand $(g / k g)$ & 870 & 774 \\
\hline
\end{tabular}

${ }^{\mathrm{a} P}, \mathrm{~K}$ : Mehlich 1; ${ }^{\mathrm{b}} \mathrm{Ca}, \mathrm{Mg}$ and $\mathrm{Al}$ : $\mathrm{KCl} 1 \mathrm{M}$ extractor one emitter per plant for a flow of $42 \mathrm{~L} / \mathrm{h}$ based on daily evapotranspiration registers recorded by a meteorological station inside the experimental station and corrected according to the guava culture coefficient $(\mathrm{Kc})$ defined by Natale (2009).

The biofertilizer used in the experiment was obtained by anaerobic fermentation and consisted of [water + fresh bovine manure] at a ratio of [1:1] (in volume), under anaerobic fermentation during 30 days, as proposed by Santos (1991). The bovine manure used was once collected during the morning as soon as produced by dairy confined Holstein cows, property of the Animal Department of Federal University of São Francisco Valley, in Petrolina County, Brazil.

Biofertilizers were biweekly distributed in a soil area of $0.283 \mathrm{~m}^{2}$ (30 cm of radius around plant stem) under water: biofertilizer ratios according to each treatment, but fixing the amount of $2.4 \mathrm{~L} \mathrm{~m}^{2}$ of plant canopy quoted by Cavalcante et al. (2008). The biofertilizer used in the

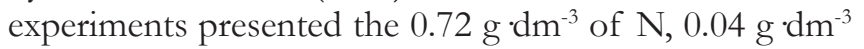
of P, $0.50 \mathrm{~g} \cdot \mathrm{dm}^{-3}$ of $\mathrm{K}, 0.20 \mathrm{~g} \cdot \mathrm{dm}^{-3}$ of Ca, $0.12 \mathrm{~g} \cdot \mathrm{dm}^{-3}$ of $\mathrm{Mg}$ and $0.39 \mathrm{~g} \cdot \mathrm{dm}^{-3}$ of $\mathrm{S}$.

All management practices for pruning, control of weeds, pests and diseases were performed following the instructions of Natale (2009). The nutrient management was carried through a fertigation system $\left(\right.$ Viqua $^{\circledR}$ venturi injector of 1" at 10 bar operating pressure), according to soil analysis (Table 1) biweekly, starting after production pruning until 20 days before harvest, using a formulated fertilizer composed by $12 \%$ of $\mathrm{N}, 5 \%$ of $\mathrm{P}, 11 \%$ of $\mathrm{K}$, $13.1 \%$ of $\mathrm{Ca}$ and $0.2 \%$ of $\mathrm{B}$. Treatments fertilized with $100 \%$ of $\mathrm{N}$ also received urea $(45 \%$ of $\mathrm{N})$. Zinc (Coda Zinc ${ }^{\circledR}, 10.4 \%$ of $\mathrm{Zn}$ ), magnesium (Coda $\mathrm{Mg}^{\circledR}$, $6.6 \%$ de $\mathrm{Mg}$ ) and iron (Codamin $\mathrm{Br}^{\circledR}, 2.0 \%$ of $\mathrm{Fe}$ ) were leaf applied.

\section{Treatments and experimental design}

The experimental design was randomized blocks with treatments distributed in a factorial arrangement $(5 \times 2)$ referring to biofertilizer concentrations [0, 2.5, $5.0,7.5$ and $10 \%$ of the fertigated volume] and mineral fertilizing with $\mathrm{N}$ [fertilization with $50 \%$ and $100 \%$ of $\mathrm{N}$ recommended by Natale (2009)], with four replications of five plants each, to evaluate three.

\section{Data gathered and statistical analyses}

During the fruit harvest time, i.e., July 2014 to August 2015, 10 fruits per parcel were manually harvested still firms at intermediate green color (yellow-green color) placed in plastic boxes and taken to the Laboratory for post-harvest fruit quality analyses. This harvest parameter 


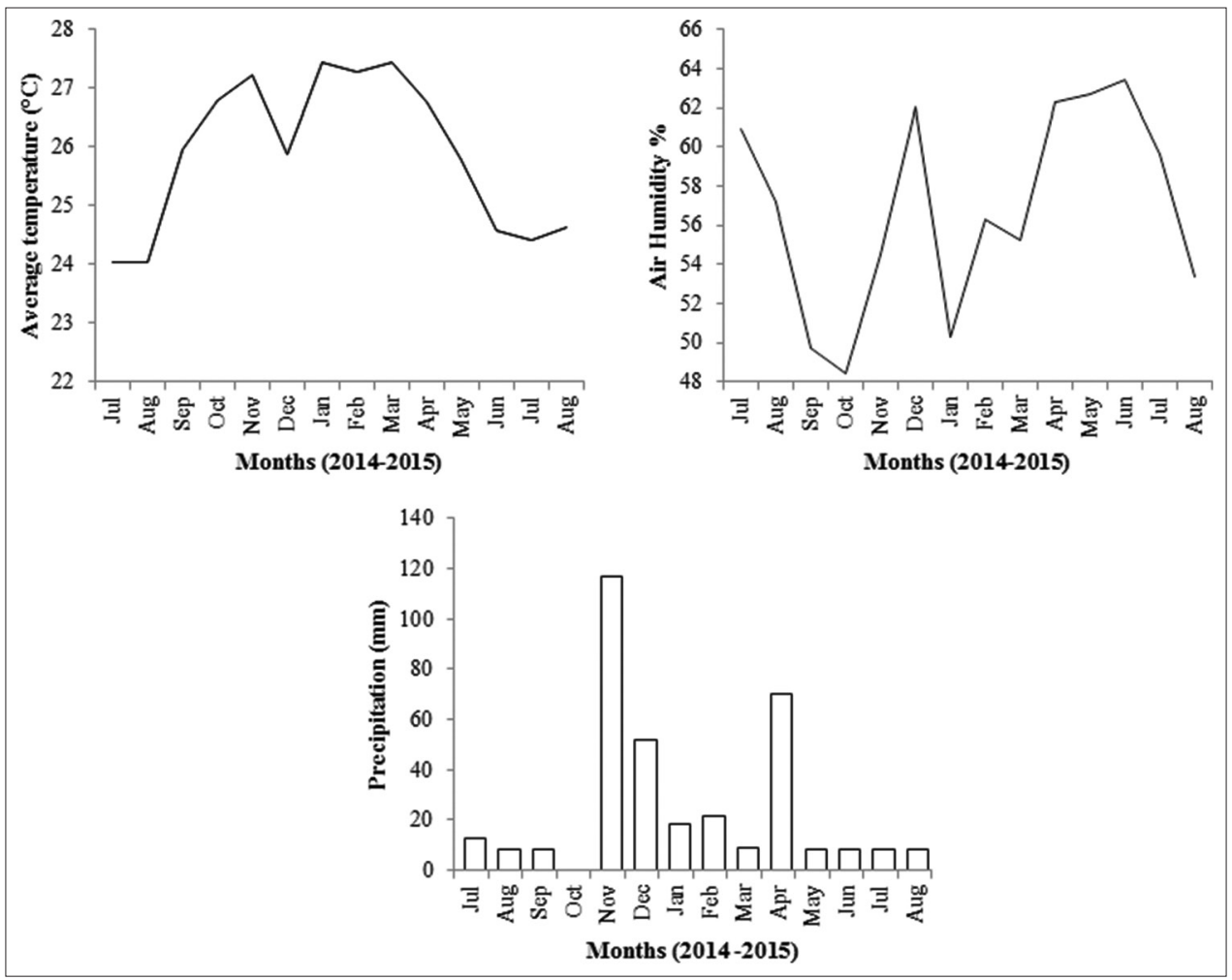

Fig 1. Average air temperature, air humidity and precipitation during the execution of the experiment.

for fruit selection was recommended by Natale (2009) for commercial farms.

The fruit analyses of the guava fruits followed the instructions of Zenebon et al. (2008) and included the usual parameters: I) the fruit mass was measured using a Sartorious ${ }^{\circledR}$ (Göttingen, Germany) brand precision balance ( $0.01 \mathrm{~g}$ precision) and expressed in $\mathrm{g}$; ii) length and width were obtained with a digital paquimeter $(0.01 \mathrm{~mm}-300 \mathrm{~mm}$, Starret ${ }^{\mathbb{R}}$ ) and expressed in $\mathrm{cm}$; iii) for the titratable acidity (TA), $20 \mathrm{~g}$ of macerated fruit pulp was taken from yellow passion fruits and brought to a final volume of $100 \mathrm{~mL}$ by adding distilled water. A $20 \mathrm{~mL}$ sample was taken from the mixture, and three to four drops of phthalein were used as an indicator. This suspension was titrated with $0.1 \mathrm{~N}$ sodium hydroxide $(\mathrm{NaOH})$. The results were expressed as a percentage; iv) the soluble solids (SS), expressed as ${ }^{\circ}$ Brix, were measured using an $\mathrm{Abbe}^{\circledR}$ refractometer (Bausch and Lomb, Rochester, NY, USA); v) The vitamin C content was defined with $5 \mathrm{~g}$ of fruit pulp taken from acerola and brought to a final volume of $100 \mathrm{~mL}$ by adding distilled water plus $1 \mathrm{~mL}$ of $1 \%$ amid solution. A $20 \mathrm{~mL}$ sample was taken from the mixture and titrated with $1 \mathrm{~N}$ iodine. The results were expressed in $\mathrm{mg} / 100 \mathrm{~g}$ of fresh fruit; vi) the pulp $\mathrm{pH}$ was measured using a Marconi ${ }^{\circledR} \mathrm{pH}$ meter; vii) fruit firmness $(\mathrm{N})$ was measured using a fruit hardness tester (Instrutherm ${ }^{\circledR}$, Brazil); viii) after chemical analyses, the relation between the soluble solids and the titratable acidity
(SS/TA ratio) was calculated; and ix) the fruit production was measured as kg per plant.

\section{Statistical analyses}

Statistical analyses included analysis of variance (ANOVA), mean separation of $\mathrm{N}$ fertilizing using Tukey's test, simple regression to separation of biofertilizers doses, using combined data of two consecutive trials. All the calculations were performed using the SAS Statistical Program, and terms were considered significant at $P \leq 0.01$.

\section{RESULTS AND DISCUSSION}

\section{Physical fruit characteristics}

Among the guava fruit physical characteristics, the interaction between biofertilizer and nitrogen fertilization were significant only for fruit width (Table 2).

As can be seen in Table 2, plants fertigated with $50 \%$ of recommended $\mathrm{N}$ presented significantly higher fruit length and width than those plants which received $100 \%$ of recommended $\mathrm{N}$. All average values quoted in Table 2 are higher than $72.9 \mathrm{~mm}$ (width) and $58.0 \mathrm{~mm}$ (length) reported by Medeiros et al. (2004) who evaluated the physical and chemical characteristics of guava fruits cv. 'Paluma' as a function of $\mathrm{N}$ doses; and also higher than $62.9 \mathrm{~mm}$ (width) and $52.7 \mathrm{~mm}$ (length) recorded by Lima et al. (2002) in study about different guava cultivars in São Francisco Valley. 
Santana, et al.: Biofertilizer and $\mathrm{N}$ on growing guava in semiarid

\begin{tabular}{|c|c|c|c|c|}
\hline & Length $(\mathrm{mm})$ & Width (mm) & Firmness (N) & Mass (g) \\
\hline Biofertilizer (B) ‘F' value & $4.30^{\star}$ & $8.48^{* *}$ & $8.36^{\star *}$ & $0.90 \mathrm{~ns}$ \\
\hline N Fertilizing (N) 'F' value & $11.28^{\star *}$ & $56.06^{\star *}$ & $0.01 \mathrm{~ns}$ & $0.01 \mathrm{~ns}$ \\
\hline $50 \%$ & $87.25 a$ & $78.27 a$ & $54.34 a$ & $176.12 a$ \\
\hline $100 \%$ & $81.44 b$ & $70.43 b$ & $54.43 a$ & $177.72 \mathrm{a}$ \\
\hline General median & 84.35 & 74.35 & 54.39 & 176.92 \\
\hline SMD & 3.63 & 2.20 & 11.69 & 26.72 \\
\hline Interaction $(B \times F)$ ' $F$ ' value & $2.50 \mathrm{~ns}$ & $6.52^{* *}$ & $0.77 \mathrm{~ns}$ & $0.54 \mathrm{~ns}$ \\
\hline Coefficient of variation (\%) & 5.62 & 3.85 & 12.30 & 19.67 \\
\hline
\end{tabular}

${ }^{*}$ Significant at $P<0.01$ probability error; *significant at $P<0.05$ probability error; ns: Non-significant, data followed by different letters in columns are significantly different according to tukey test $(P<0.01)$; SMD: Significant minimum difference

Fruit width and length were affected by biofertilizer doses (Fig. 2A and 2B), i.e., the average values of both variables decreased with biofertilizer dose increasing. The largest fruit size (width and length) recorded to lower biofertilizers doses can be attributed to the $\mathrm{N}$ supply associated with biofertilizer action that contains humic substances able to interact with $\mathrm{N}$ availability (Cunha et al., 2015) and even in small amounts provide the $\mathrm{N}$ adequate supply for guava. It is important to point that fruit width showed in Fig. 2B refers to plants fertigated with $100 \%$ of recommended N, because those fruits produced by guava plants fertilized with $50 \%$ of recommended $\mathrm{N}$ presented no adjustment to any regression model.

The fruit firmness values ranged from $43.90 \mathrm{~N}(0.0 \%$ of biofertilizer) to $63.68 \mathrm{~N}$ (2.5\% of biofertilizer) (Fig. 2C), a result similar to that reported by Mesquita et al. (2007) who evaluated the effect of two bovine biofertilizers (simple and enriched) on papaya cv. 'Baixinho de Santa Amália'. This way Paiva et al. (2009) detach that the molecular processes responsible for major fruit changes during ripening is related to fruit firmness, which is one of the key attributes that guarantee fruit quality for in natura consumption, and fruit firmness is related with $\mathrm{K}$ nutrition, since, according to Lima et al. (2008), K supports the maintenance of cell turgor and it contributes to tissue resistance, but the NK combination affects fruit firmness along the maturation stages. Additionally, the biofertilizer used in the present experiment had high $\mathrm{K}$ levels (Table 2), which probably favored the fruit firmness increasing with a maximum value at $2.5 \%$ of biofertilizer (Fig. 2C). Whether compared to the scientific literature, the average values of Fig. $2 \mathrm{C}$ are much higher than those obtained by Lima et al. (2008) in study about guava 'Paluma' in São Francisco Valley, but lower than the average reported by Pérez-Barraza et al. (2015) in Mexico for the same guava cultivar.

\section{Chemical fruit characteristics}

The biofertilizer x $\mathrm{N}$ fertilizing interaction was significant for all chemical variables evaluated, while the $\mathrm{N}$ fertilizing simple effect was verified for soluble solids (SS), soluble solids/titratable acidity ratio (SS/AT) and vitamin C (Vit.C), with higher values recorded to those plants fertilized with $100 \%$ of $\mathrm{N}$ (Table 3 ).

Plants of all treatments produced fruits compatible with the current legislation requirements (MAPA, 2000) i.e., minimum 7.0 SS, and higher than $7.41 \pm 0.14$ range recorded by Batista et al. (2015) for guava cv. Paluma grown in São Francisco Valley (Table 3). Nitrogen plays an important role for leaf sugar biosynthesis, which can be translocated to fruits and increase fruit SS concentration (Souza et al., 2010) that should have occurred in the present study, since the highest SS average was recorded at the higher $\mathrm{N}$ (Table 3). Biofertilizer doses significantly affected guava SS, but there was no adjustment to any regression model.

Titratable acidity of fruits from plants fertigated with $100 \%$ of $\mathrm{N}$ decreased with biofertilizer doses increasing (Fig. 3A). Increasing biofertilizer doses also increased the supply of nutrients related to organic acids metabolism, especially potassium, because the biofertilizer used in the experiment present high $\mathrm{K}$ content (Table 2) and, according to (Busato et al., 2011) larger $\mathrm{K}$ amounts stimulates TA reduction due to acids degradation, especially malic acid by fruits transpiration. Independently of biofertilizer dose, all TA values recorded in the resent study are higher than those reported by Lima et al. (2008), lower than Oliveira et al. (2014) results, both of them in study about guava, but all of them are higher than minimum value required by Brazilian government, which is $0.4 \%$ (MAPA, 2000). Accordingly Chitarra and Chitarra (2005) detach that less acid fruits are more recommended to consumption as fresh fruit, while more acid fruits are required for food industry.

The SS/TA ratio as a function of biofertilizer doses presented no adjustment to any regression model. On the other hand, there was simple effect of $\mathrm{N}$ fertigation with superiority for plants fertigated with $100 \%$ of $\mathrm{N}$ (Table 3), which can be explained by the $\mathrm{N}$ action that favored the $\mathrm{SS}$ increase through the sugar translocation from leaves to 


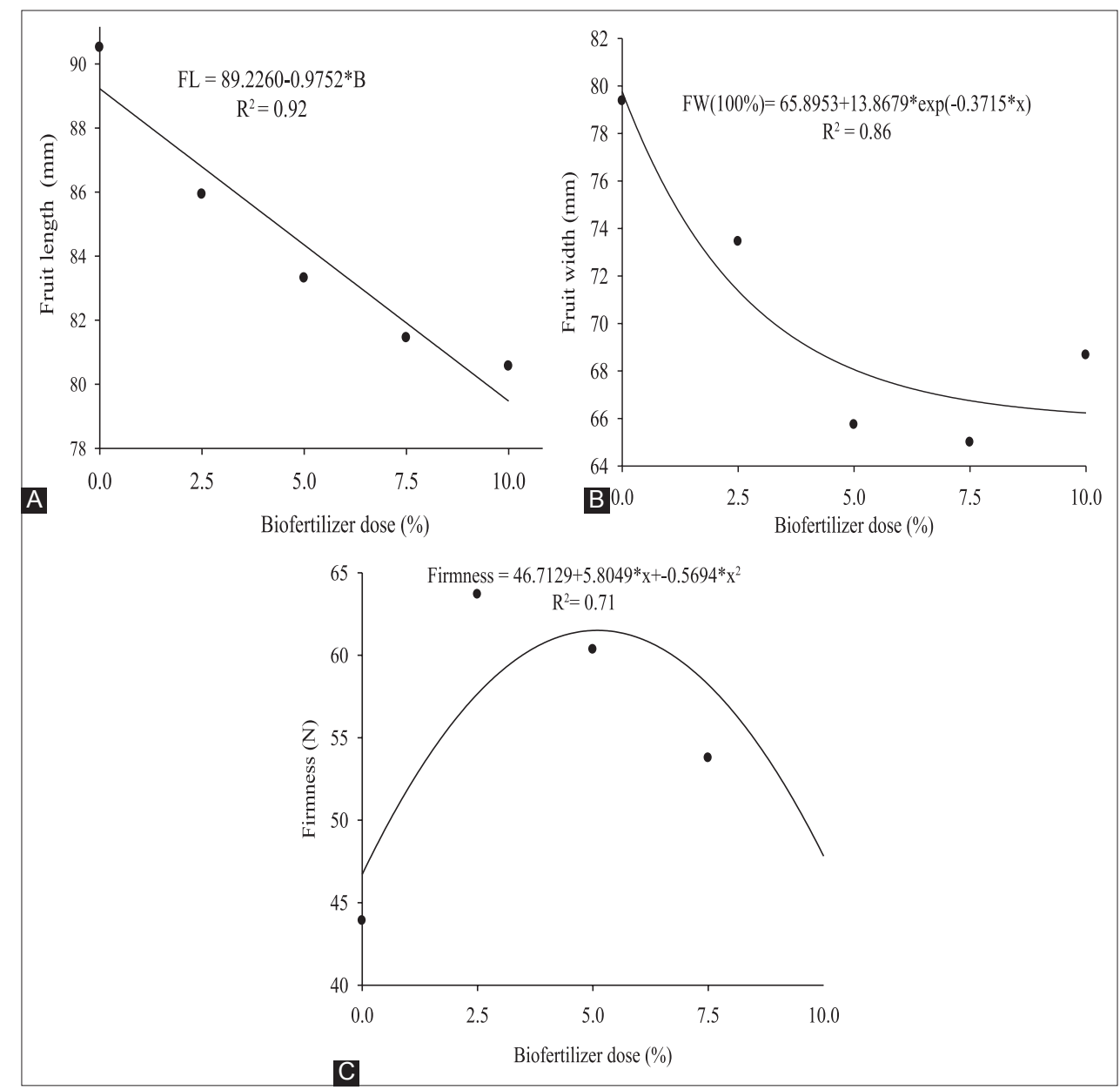

Fig 2. Fruit characteristics [length (A), width $(B)$ and firmness $(C)$ ] of guava as a function of biofertilizer concentrations.

\begin{tabular}{|c|c|c|c|c|c|c|}
\hline & SS (Brix) & TA (\%) & SS/TA & Vit.C (mg/100g) & $\mathrm{pH}$ & Fruit production (kg perplant) \\
\hline Biofertilizer (B) ‘F’ value & $60.17^{\star *}$ & $3.31^{*}$ & $41.11^{\star \star}$ & $7.31^{\star \star}$ & $12.92^{\star *}$ & $1.12^{*}$ \\
\hline N Fertilizing (N) 'F' value & $26.49^{\star *}$ & $0.30 \mathrm{~ns}$ & $13.51^{\star \star}$ & $128.52^{\star \star}$ & $1.59 \mathrm{~ns}$ & $20.84^{*}$ \\
\hline $50 \%$ & $8.7 b$ & $0.49 a$ & $17.79 \mathrm{~b}$ & $70.08 b$ & $4.33 a$ & $40.04 a$ \\
\hline $100 \%$ & $9.7 \mathrm{a}$ & $0.49 a$ & $18.59 a$ & $79.88 a$ & $4.35 a$ & $35.93 b$ \\
\hline General median & 9.2 & 0.49 & 18.19 & 74.98 & 4.34 & 37.98 \\
\hline SMD & 0.18 & 0.01 & 0.45 & 1.82 & 0.03 & 9.21 \\
\hline Interaction $(B \times F)$ 'F' value & $16.68^{* *}$ & $3.25^{*}$ & $17.06^{\star *}$ & $13.62^{* *}$ & $16.93^{* *}$ & $1.06 \mathrm{~ns}$ \\
\hline Coefficient of variation (\%) & 2.68 & 3.20 & 3.29 & 3.16 & 0.90 & 37.36 \\
\hline
\end{tabular}

${ }^{*}$ Significant at $P<0.01$ probability error; *significant at $P<0.05$ probability error; ns: Non-significant, data followed by different letters in columns are significantly different according to tukey test $(P<0.01)$; SMD: Significant minimum difference

fruits (Souza et al., 2010). In this sense Batista et al. (2015) evaluated guava fruit quality and found SS/AT of 18.87, therefore compatible with 18.59 contained in Table 3. According to Chitarra and Chitarra (2005), SS/TA ratio is one of the chemical variables commonly used to determine the fruit palatability and maturation, since it is a flavor indication. The average values of SS/AT of the present study are compatible to the current legislation requirements (MAPA, 2000), which requires least 17.5.
Vit.C guava concentration enhanced with biofertilizer doses increasing (Fig. 3B) that is in agreement with Dias et al. (2011) and Freire et al. (2010) who suggested that organic acids and sugars present in organic sources available for plants, such as biofertilizer can increase fruit vitamin $\mathrm{C}$ concentration. In general, all treatments produced fruits with Vit.C concentrations compatible to legislation requirements, i.e., $40 \mathrm{~g} / 100 \mathrm{~g}$. Guava plants fertigated with $100 \%$ of $\mathrm{N}$ with Vit.C concentration 


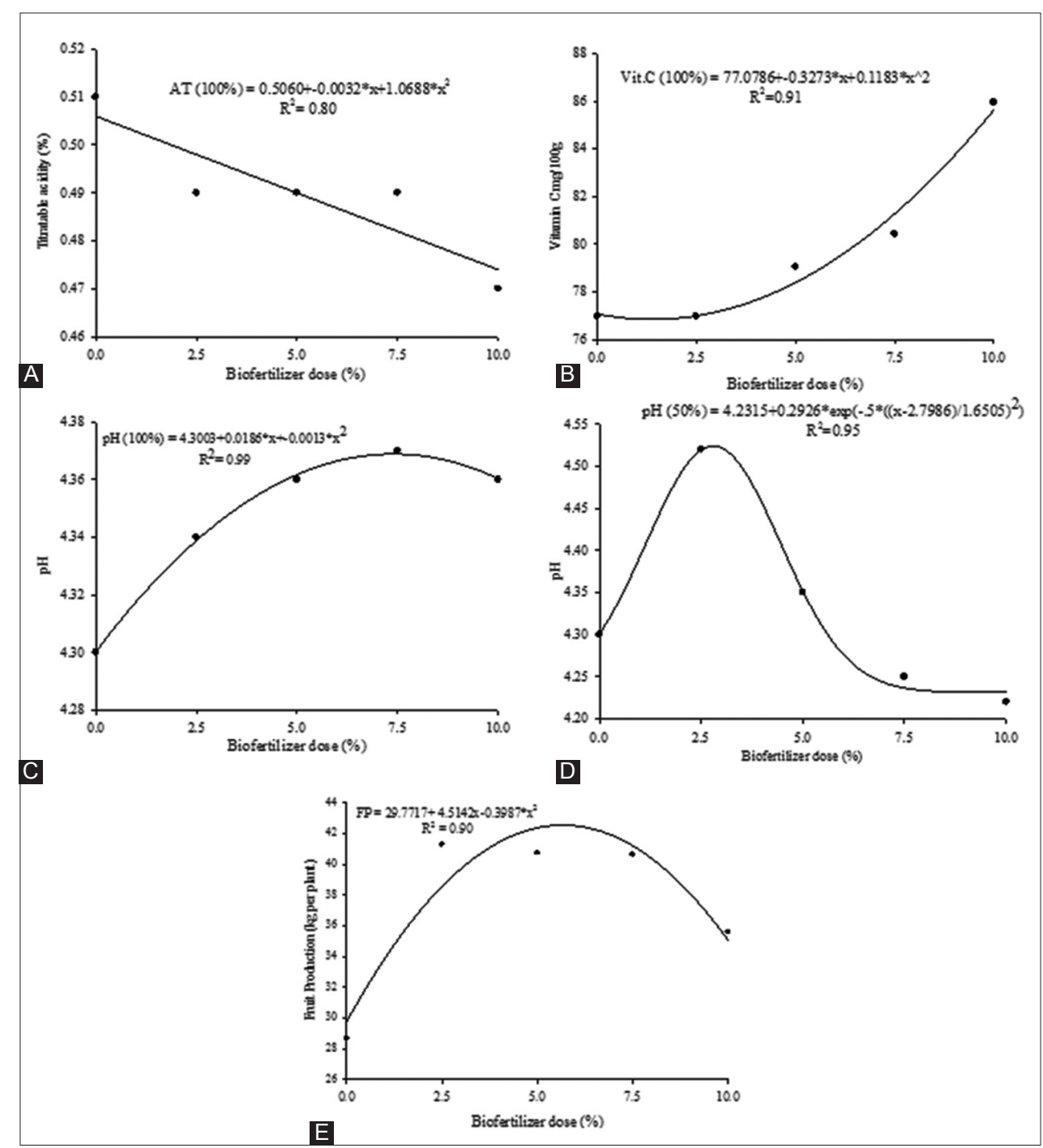

Fig 3. Chemical fruit characteristics [titratable acidity (A), vitamin $\mathrm{C}(\mathrm{B})$ and $\mathrm{pH}(\mathrm{C}$ and $\mathrm{D})$ ] and fruit production (E) of guava as a function of biofertilizer doses. In the equations $50 \%$ and $100 \%$ means plants fertilized with $50 \%$ and $100 \%$ of recommended $\mathrm{N}$.

higher than $73.2 \mathrm{~g} / 100 \mathrm{~g}$ registered by Malta et al. (2013), but lower than $89.78 \mathrm{~g} / 100 \mathrm{~g}$ average reported by Lima et al. (2002) for guava trees grown in São Francisco Valley. Indeed, Rufino et al. (2009) ague that vitamin C fruit concentration can vary depending on several factors such as light intensity, air temperature, air humidity and rainfall, of the region where plants are grown. In this sense, during the last 60 days before harvest of the first trial (December 2015 and January 2016) it was registered $70 \mathrm{~mm}$ rainfall which may have effects on this vitamin $\mathrm{C}$ fruit concentration.

Fruit $\mathrm{pH}$ depended on biofertilizer doses (Table 3). Fruit $\mathrm{pH}$ increased until reach a peak at $7.5 \%$ (plants fertigated with $50 \%$ of $\mathrm{N}$ ) and $2.5 \%$ (plants fertigated with $100 \%$ of $\mathrm{N}$ ) followed by a consecutive decay, as can be seen in Fig. 3C and 3D, respectively. According to Busato et al. (2011), high fruit $\mathrm{pH}$ values are related to $\mathrm{K}$ absorption during fruit maturation, because ion $\mathrm{K}^{+}$accumulation result in cation exchange with $\mathrm{H}^{+}$, thus increasing fruit $\mathrm{pH}$. This can be happened in the present study because the biofertilizer used is $\mathrm{K}$ concentrated $\left(0.50 \mathrm{~g} \mathrm{dm}^{-3} \mathrm{~K}\right)$, according to Marrocos et al. (2012) reference. $\mathrm{pH}$ is a chemical variable that measures fruit acidity, therefore it can indicate the treatment necessary to preserve processed fruits (Chitarra and Chitarra, 2005). All treatments surpassed the maximum value required by Brazilian legislation (4.2) (MAPA, 2000). Evangelista and Vieites (2006) also found higher values than the maximum set by MAPA (2000), while Batista et al. (2015) found a $\mathrm{pH}$ range of $3.92 \pm 0.07$, thus within the standard defined by MAPA (2000).

\section{Fruit production}

Guava fruit production (kg per plant) for two production cycles was significantly affected by both $\mathrm{N}$ fertigation and biofertilizer doses (Table 3). Plants fertigated with $50 \%$ of $\mathrm{N}$ produced $4 \mathrm{~kg}$ more than those fertigated 
with $100 \%$ of $\mathrm{N}$, which corresponds to an estimated fruit yield of 25 tons per hectare (Table 3), a value higher than the most recent national data publication, which is $22,699 \mathrm{t} / \mathrm{ha}$ (IBGE, 2016). On the other hand non biofertilized plants produced almost $21 \%$ less fruits if compared to Brazilian statistics.

Biofertilizer doses had significant effect on guava fruit production (Table 3) with a large quantitative range from $28.69 \mathrm{~kg}$ per plant or $17.96 \mathrm{t} / \mathrm{ha}$ (no biofertilizing) to the calculated peak of $42.54 \mathrm{~kg}$ per plant $(26.59 \mathrm{t} / \mathrm{ha})$ recorded at $5.66 \%$ of biofertilizer. This average quantitative difference of $13.85 \mathrm{~kg}$ per plant (8.66 t/ha, or $48.27 \%$ ) should be evaluated by commercial farmers to define the economic viability of bovine biofertilizer through fertigation system.

Ramos et al. (2010) in study about guava cv. Paluma at five years old recorded in maximum $55.82 \mathrm{~kg}$ per plant, while Amorim et al. (2015) in study with seven years old guava plants recorded $175 \mathrm{~kg}$ per plan, this higher than $40 \mathrm{~kg}$ per plant registered in the present study. Accordingly, plant age has a direct impact on guava fruit production and the plants of the present study were 2 years old at the first fruit harvest. Accordingly, Lima et al. (2008) evaluated $\mathrm{N}$ doses on 1.5 years old guava plants and registered $25 \mathrm{~kg}$ per plant.

\section{CONCLUSION}

The results of this study indicate that: i) fruit quality of guava depends on bovine biofertilizer and $\mathrm{N}$ fertigation; ii) biofertilizer enhanced the fruit firmness, vitamin $\mathrm{C}$ and $\mathrm{pH}$, beyond titratable acidity reduction of guava; iii) it is possible to recommend fertigation with biofertilizer at $5.66 \%$, independently of $\mathrm{N}$ fertilizing with $50 \%$ or $100 \%$ of recommended $\mathrm{N}$; and iv) bovine biofertilizer is an important key to the production of guava under semiarid climate.

\section{ACKNOWLEDGEMENTS}

The authors gratefully thank to CNPq (National Council for Scientific and Technological Development) for granting the financial support necessary to carry out the research under grant number 453871/2014-3, and to FACEPE (Foundation for Support of Science and Technology of Pernambuco State) for granting the scholarships under grant number IBPG-0245-5.01/14.

\section{Author's Contributions}

This experiment is an interdisciplinary one developed under field conditions with fruit analysis in laboratory. This manuscript is part of the M.Sc. Thesis (Plant Production) of Elisson Alves Santana advised by Prof. Dr. Ítalo Herbert Lucena Cavalcante and Profa. Dra. Karla dos Santos Melo de Souza. Thus, all authors accompanied all practices of the research, but more specifically Diogenes de Souza Brito and Raí Nascimento do Carmo acted on field data gathering, fruit analysis in laboratory and data preparations for statistical analysis.

\section{REFERENCE}

Amorim, D. A., D. E. Rozane, H. A. Souza, V. C. Modesto and W. Natale. 2015. Adubação nitrogenada e potássica em goiabeira 'Paluma': I. Efeito na produtividade e na qualidade dos frutos para industrialização. Rev. Bras. Fruticultura. 37: 201209.

Batista, P. F., M. A. C. Lima, D. C. G. Trindade and R. E. Alves. 2015. Quality of different tropical fruit cultivars produced in the lower basin of the São Francisco Valley. Rev. Cienc. Agron. 46: 176-184.

Busato, C. C. M., A. A. Soares, G. C. Sediyama, S. Y. Motoike and E. F. Reis. 2011. Manejo da irrigação e fertirrigação com nitrogênio sobre as características químicas da videira 'Niágara rosada'. Cienc. Rural. 41: 1183-1188.

Cavalcante, Í. H. L., L. F. Cavalcante, G. D. Santos, M. Z. BeckmannCavalcante and S. M. Silva. 2012. Impact of biofertilizers on mineral status and fruit quality of yellow passion fruit in Brazil. Commun. Soil. Sci. Plan. 43: 2027-2042.

Cavalcante, L. F., Í. H. L. Cavalcante and G. D. Santos. 2008. Micronutrient and sodium foliar contents of yellow passion plants as function of biofertilizers. Fruits. 60: 1-8.

Chavez, J. C. L. and A. I. Z. Torres. 2012. Conventional guava in Zitacuaro's Region, Michoacan, Mexico. Sustain. Agric. Res. 1: $19-25$.

Chitarra, M. I. F. and A. B. Chitarra. 2005. Pós-colheita de Frutas e Hortaliças: Fisiologia e Manuseio, $2^{\text {th }}$ ed. UFLA, Lavras, MG.

Cunha, M. S., Í. H. L. Cavalcante, A. C. Mancin, F. G. Albano and A. S. Marques. 2015. Impact of humic substances and nitrogen fertilizing on the fruit quality and yield of custard apple. Acta Sci. Agron. 37: 211-218.

Dias, T. J., L. F. Cavalcante, J. L. O. Freire, J. A. M. Nascimento, M. Z. Beckmann-Cavalcante and G. P. dos Santos. 2011. Qualidade química de frutos do maracujazeiro-amarelo em solo com biofertilizante irrigado com águas salinas. Rev. Bras. Eng. Agric. Ambient. 15: 229-236.

Evangelista, R. M. and R. L. Vieites. 2006. Avaliação da qualidade de polpa de goiaba congelada comercializada na cidade de São Paulo. Segurança Aliment Nutr. 13: 76-81.

Freire, J. L. O., L. F. Cavalcante, A. M. Rebequi, J. C. Nunes, T. J. Dias and Í. H. L. Cavalcante. 2010. Atributos qualitativos do maracujá amarelo produzido com água salina, biofertilizante e cobertura morta no solo. Rev. Bras. Cienc. Agrar. 5: 102-110.

Gross, A., R. Arusi, P. Fine and A. Nejidat. 2008. Assessment of extraction methods witf fowl manure for the production of liquid organic fertilizers. Bioresour Technol. 99: 327-334.

IBGE. 2016. Banco de Dados Agregados. Available from: http://www. ibge.gov.br/estadosat/. [Last cited on 2016 May 20].

Leonel, S., J. F. Araújo and M. A. Tecchio. 2015. Biofertilização e adubação organomineral: Concentração de nutrientes na folha e produtividade de frutos de pinheira. Irriga. 1: 40-51.

Lima, M. A. C. and J. S. Assis. 2002. Caracterização dos frutos de 
goiabeira e seleção de cultivares na Região do Submédio São Francisco. Rev. Bras. Fruticultura. 24: 273-276.

Lima, M. A. C., L. H. Bassoi, D. J. Silva, P. S. Santos, P. C. Paes, P. R. A. Ribeiro and B. F. Dantas. 2008. Effects of levels of nitrogen and potassium on yield and fruit maturation of irrigated guava trees in the São Francisco Valley. Rev. Bras. Fruticultura. 30: 246-250.

Malta, A. O., R. C. Araújo, J. G. F. Medeiros, N. P. Costa, L. P. M. Azerêdo and J. A. Dias. 2013. Características químicas dos frutos da goiabeira 'Paluma' em função da adubação orgânica e mineral. Rev. Educ. Agríc. Super. 28: 120-125.

MAPA. 2000. Instrução Normativa n. 01, de 07 de Janeiro de 2000: Aprova o Regulamento Técnico Geral Para Fixação dos Padrões de Identidade e Qualidade Para Polpa de Fruta. Ministério da Agricultura e do Abastecimento, Brasília, GO.

Marrocos, S. T. P., J. N. Junior, L. C. Grangeiro, M. M. Q. Ambrosio and A. P. A. Cunha. 2012. Composição química e microbiológica de biofertilizantes em diferentes tempos de decomposição. Rev. Caatinga. 25: 34-43.

Marschner, H. 2012. Mineral Nutrition of Higher Plants, $3^{\text {th }}$ ed. Academic Press, New York, NY.

Medeiros, B. G. S., J. P. G. Gouveia, F. A. C. Almeida, C. F. A. Ribeiro and S. M. A. Duarte. 2004. Características físicas da goiaba (Psidium guajava L.): Efeito da adubação nitrogenada. Rev. Bras. Prod Agroind. 6: 47-53.

Mesquita, E. F., L. F. Cavalcante, S. C. Gondim, Í. H. L. Cavalcante, F. A. R. Araújo and M. Z. Beckmann-Cavalcante. 2007. Produtividade e qualidade de frutos do mamoeiro em função de tipos e doses de biofertilizantes. Semin. Cienc Agrar. 28: 589-596.

Natale, W. 2009. Adubação, nutrição e calagem na goiabeira. In: Natale, W., D. E. Rozane, H. A. Souza and D. A. Amorim (Eds.), Cultura da Goiaba do Plantio à Comercialização, FCAV, UNESP, Jaboticabal, SP, pp. 257-280.

Oliveira, R. F., L. M. M. Santos and E. Clemente. 2014. Physicochemical characteristics of guava "Paluma" submitted to osmotic dehydration. Acta Sci.Technol. 36: 733-737.

Paiva, E. P., M. S. Lima and J. A. Paixão. 2009. Pectina: Propriedades químicas e importância sobre a estrutura da parede celular de frutos durante o processo de maturação. Rev. Iberoam. Polím. 10: 196-211.

Pérez-Barraza, M. H., J. A. Ouna-García, J. S. Padilla-Ramirez, R. Sánchez-Lucio, Y. Nolasco-González and E. GonzálezGaona. 2015. Fenología, productividad y calidad de fruto de Guayaba pula crema y rosa en clima tropical en México. Interciencia. 40: 198-203.

Pires, A. A., H. P. Monnerat, C. R. Marciano, L. G. R. Pinho, P. D. Zampirolli, R. C. Rosa and R. A. Muniz. 2008. Efeito da adubação alternativa do maracujazeiro amarelo nas características químicas e físicas do solo. Rev. Bras. Cienc. Solo. 32: 1997-2005.

Ramos, D. P., A. C. Silva, S. Leonel, S. M. Costa and E. R. D. Junior. 2010. Produção e qualidade de frutos da goiabeira 'Paluma' submetida à diferentes épocas de poda em clima subtropical. Rev. Ceres. 57: 659-664.

Rufino, M. S. M., F. A. N. Fernandes, R. E. Alves and E. S. Brito. 2009. Free radical-scavenging behavior of some North-East Brazilian fruits in a DPPH system. Food Chem. 114: 693-695.

Santos, A. C. V. 1991. Efeitos nutricionais e fitossanitário do biofertilizante líquido a nível de campo. Rev. Bras. Fruticultura. 13: $275-279$.

Santos, J. G. R., R. Andrade, P. O. Galdino, A. S. F. Linhares, P. M. E. Maia and A. S. Lima. 2014. Qualidade da produção da bananeira Nanicão em função do uso de biofertilizantes. Rev. Bras. Eng. Agric. Ambient. 18: 387-393.

Senthilkumar, M., S. Ganesh, K. Srinivas and P. Panneerselvam. 2014. Influence of fertigation and consortium of bio fertilizer on photosynthesis, chlorophyll content, yield parameters and yield of banana cv. Robusta (AAA). Plant Arch. 14: 387-391.

Souza, J. A. R., D. A. Moreira, P. A. Ferreira and A. T. Matos. 2010. Avaliação de frutos de tomate de mesa produzidos com efluente do tratamento primário da água residuária da suinocultura. Eng. Agric. 18: 198-207.

Zenebon, O., N. S. Pascuet and P. Tiglea. 2008. Métodos FísicoQuímicos para Análise de Alimentos, $4^{\text {th }}$ ed. Instituto Adolfo Lutz, São Paulo, SP. 